$\xi=-1$

\title{
A Comparative Study on Shear Wall Concept in Accordance to its Seismic Behavior
}

\author{
Deepna $\mathbf{U}^{1 *}$, Arjun S Menon ${ }^{2}$, S.Balamurugan ${ }^{3}$ \\ ${ }^{1}$ Post Graduate Student, Structural Engineering, School of civil and chemical engineering, VIT - Vellore, India \\ ${ }^{2}$ Structural Engineer, Sreegiri Consultants, Ernakulam, India. \\ ${ }^{3}$ Assistant Professor(Sr), School of civil and chemical engineering, VIT-Vellore, India \\ *Corresponding author E-mail:udeepna@gmail.com
}

\begin{abstract}
The consequences of lateral loads like earthquake loads, wind loads and blast forces are achieving utmost concern nowadays. Imparting sufficient strength and stability in counter to the lateral loads is one of the major challenges faced by every designer. Therefore Proper understanding of the Seismic performance of different types of shear walls is necessary for structural engineers so as to safeguard the structure against lateral loads. The present paper describes the comparison of the seismic performance of high rise buildings and optimizing the thickness of RCC shear wall, Steel Plate Shear Wall (SPSW) and composite shear wall for (G+20) stories. The design and analysis of the building with RCC shear wall, steel plate shear wall and composite shear wall is carried out using software ETABS. Effect of varying thickness of shear panels and comparison of the results of story drift and story shear is presented.
\end{abstract}

Keywords: Base Shear, Composite Shear Wall, Steel Plate Shear Wall, Story drift, Story displacement

\section{Introduction}

In high rise structures a Shear wall is one of the primary element which is used to resist the lateral forces exerted by earthquakes around the world. Past researches indicated that the reinforced concrete (RC) Shear walls exhibits a sudden loss in lateral capacity because of the wall corner and web crushing experienced in the plastic zone. Also, it was revealed that large shear distortions in shear walls may give rise to a low energy dissipation capacity. Due to these reasons, Steel plate shear walls (SPSW) and Steel$\mathrm{RC}$ composite shear walls have emerged so as to extenuate the shortcomings of RC shear wall. A steel plate shear wall system has adequate stiffness for control of structure displacement, ductile failure mechanism and high energy absorption. Generally, a steel plate wall with two boundary columns and horizontal floor beams constitutes a steel plate shear wall system. A vertical plate girder action is exhibited by the steel plate wall and the two boundary columns together. Decreasing energy dissipation capacity, reduced shear strength and dropping stiffness of the system becomes the most notable drawback of a steel shear wall due to the buckling of the compression zone of the wall. But, when it comes to Composite shear wall, which is constituted with steel plates connected with reinforced concrete panels on one or both sides of the steel infill plates with bolts at regular intervals are expected to combine the advantages of steel and concrete shear walls. The layer of pre-cast or cast-in-situ reinforced concrete panel contributes to safeguard against fire, explosions, etc.

Soheil Shafaeia et al(1) studied the Nonlinear behavior of concrete stiffened steel plate shear wall (CSPSW) with an opening. According to the paper, CSPSW provides greater shear capacity and higher energy dissipation in comparison with its corresponding SPSW. Sina Nassernia and Hossein Showkati (2)examines the theoretical and experimental aspects of specific types of tensile- braced mid-span steel plate shear walls and the effects of circular opening on the system. The mid-span implementation of shear walls is meant to avoid the need for strengthening the surrounding principal columns. The results indicate appropriate and acceptable behavior of the system even in high levels of drift. D. Dan et al (3) conducted experimental tests and a theoretical study on composite steel-concrete shear walls with steel encased profiles (CSRCW).Nonlinear analysis of the system was carried out emphasizing the steel profile to concrete connection, and also conducted a comparative study on the performance of shear walls with various steel shape encased profiles with characteristic shear walls with reinforced concrete. Natalia Egorova et al (4) examined the ring-shaped steel plate shear wall of which constitutes a peculiar arrangement of cut-outs leading to ring shapes which is efficient in alleviating plate buckling. The study concluded that in comparison to the thin steel plate shear wall which is unstiffened the load deformation response of the ensuing RS-SPSW structure is found to illustrate full hysteretic behavior and also imparts significantly advanced stiffness. S.A.A. Hosseinzadeh and Mohsen Tehranizadeh (5) investigated the nonlinear performance of steel plate shear walls (SPSWs) which is stiffened with extensive rectangular shaped apertures which are utilized as windows or doors in structures. Results showed that the establishment of the stiffened apertures in various SPSWs enhances the ultimate strength and stiffness of the structure, at the same time more or less leading to a declining ductility ratio.

Masoud Hoseinzadeh Asla and Mahna Safarkhanib (6) examined a distinct genre of reduced beam section for a steel plate shear wall (SPSW). By adopting the schemed slotted beam model in shear walls with various story height to length ratios and analyzing, the author came to the conclusion that declining height to length ratio of the wall leads to drop in ductility. Nam H. Nguyen and Andrew S. Whittaker(7) conducted a numerical examination of composite walls which are essentially a steel-plate concrete (SC) wall mak- 
ing use of finite element (FE) program ABAQUS. The comparison of the results with the data from reversed cyclic, inelastic tests of four large-scale SC wall piers with an aspect ratio of 1.0 was carried out. Sandip Dey and Anjan K. Bhowmick(8) studied the Nonlinear seismic responses of a 4-storey and 6-storey composite plate shear wall (C-PSW) are studied. As per the Nonlinear seismic analysis conducted results depicts that composite plate shear walls, operate in a stable and ductile manner even in increased seismic activity areas. Siamak Epackachi et al (9) presents results of numerical studies on the in-plane monotonic response of steel-plate concrete (SC) composite shear wall piers. The baseline FEM model was precisely legitimized with the usage of data from reversed cyclic, inelastic in-plane tests of four large-scale SC wall piers. Qiuhong Zhao and Abolhassan Astaneh-Asl(10) investigated the experimental research on three-story composite shear wall specimens and the test results are examined and validated with FEM results.

In accordance with the literature review we feel that the understanding the Seismic performance of different types of shear walls is necessary for structural engineers. Thus RCC, Steel plate and Composite Shear wall is investigated by utilizing finite element method. In this paper the storey displacement, storey drift and base shear is compared by varying the thickness of RCC and thickness of steel plate in Steel plate shear wall and composite shear walls.

\section{Finite Element Analysis}

The study is divided into three different parts. In this present paper, three different materials are considered for the shear wall. In phase one: five RCC shear walls of thickness 200, 225, 250, 275 and 300 $\mathrm{mm}$ are selected to study the seismic behaviour of RCC shear wall. In phase two: steel plates of thickness $24,26,28,30$ and $32 \mathrm{~mm}$ are utilized to investigate the seismic behaviour of steel plate shear wall. In phase three: steel plates of thickness 24, 26, 28,30 and 32 $\mathrm{mm}$ are used as steel infill plates in RCC for composite shear wall. The storey displacement, storey drift and base shear is compared for RCC, steel plate and composite shear wall.

* The following assumptions are made in this study

- Linear analysis of the 20 storey building is performed. This implies that the obeying hookes law

- Damping has not been considered in the study

- Openings in the shear wall is not considered foe analysis.

- Only seismic analysis along EQ-X and EQ-Y directions are taken into consideration in this paper.

\subsection{Materials and Methods}

\begin{tabular}{|c|c|c|}
\hline Material properties & STEEL & COCRETE \\
\hline $\begin{array}{c}\text { Weight per unit Vol- } \\
\text { ume }\left(\mathrm{kN} / \mathrm{m}^{3}\right)\end{array}$ & 78.8196 & 30 \\
\hline $\begin{array}{c}\text { Mass per unit volume } \\
\left(\mathrm{kg} / \mathrm{m}^{3}\right)\end{array}$ & 7827.1 & 2400.7 \\
\hline $\begin{array}{c}\text { Modulus of Elasticity, } \\
\mathrm{E} \mathrm{(} \mathrm{MPa})\end{array}$ & 199948 & 27386.13 \\
\hline Poissons ratio & 0.3 & 0.2 \\
\hline $\begin{array}{c}\text { Coefficient of thermal } \\
\text { expansion, A (1/C })\end{array}$ & 0.0000117 & 11410.89 \\
\hline $\begin{array}{l}\text { Shear Modulus, G } \\
(\mathrm{MPa})\end{array}$ & 76903.08 & \\
\hline
\end{tabular}

ETABS software version 2106 was utilised for all analysis purposes. The project is located in Ernakulam. The main structure is a 20 -storey hospital building. The total height of the building is about $80 \mathrm{~m}$. The elevation of the structure is shown in Figure 1. ISMB 600 is used as horizontal and vertical boundary elements for the Steel plate Shear wall. The grade of steel used for steel plate is
Fe 250. The wind load is taken as per IS 875-Part 3-1987. For earthquake considerations, according to the IS code [1], its seismic zone is 3 , importance factor is 1.5 , zone factor is 0.16 and soil type is 3 . The response reduction factor is 5 .

The assignment of thin shell elements in ETABS is shown in figure 2.Thin shell elements are utilized in properly modelling the plate components of shear wall systems, namely, the steel infill plates and the reinforced concrete panels. For meshing, maximum size of mesh is $1 \mathrm{~m}^{2}$.

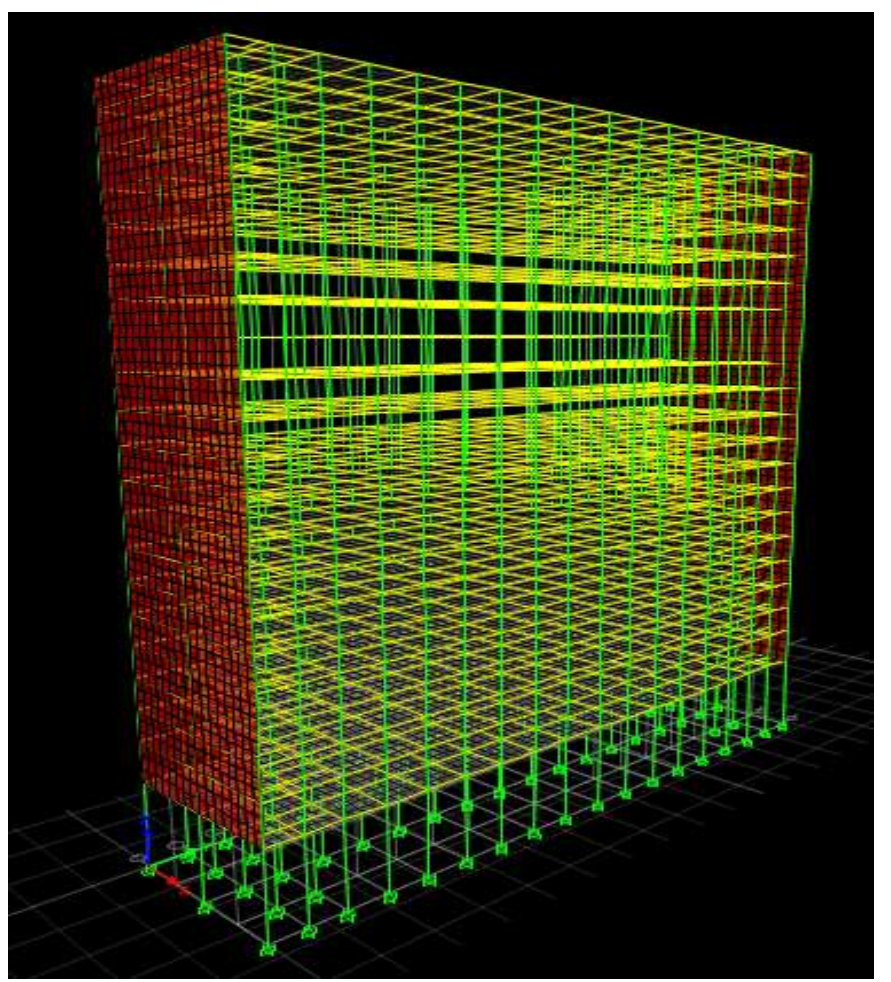

Fig 1: Elevation of the structure

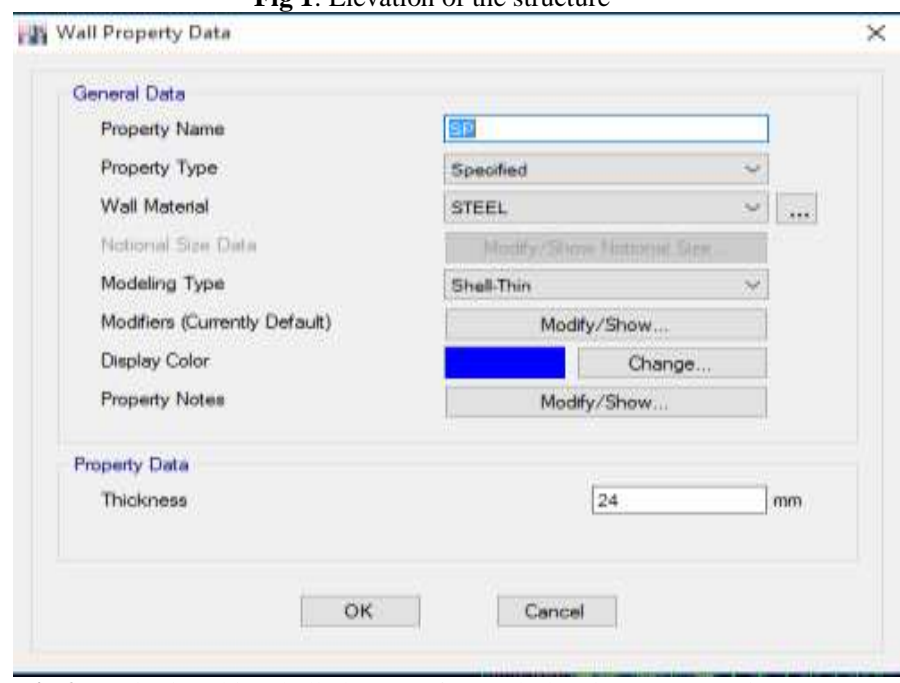

Fig 2: Assigning thin-Shell elements for steel plate in ETAB version 2016

\section{Results and Discussions}

a. Base Shear.

- $\quad$ The base shear for the RCC shear wall, shear wall with the steel plates and Composite Shear wall is depicted in Figure 3, 4 and 5.

- $\quad$ As per IS 1893-Part 1-2016 design seismic base shear is the horizontal lateral force in the considered direction of earthquake shaking that the structure shall be designed for. 
- Figure 3. Depicts that the base shear slightly reduces when thickness of the RCC shear panel decreases.

- Figure 4. Depicts that the base shear is slightly decreased when thickness of the steel plate decreases.

- $\quad$ Figure 5. Depicts that the base shear slightly decreases as the thickness of the steel infill plate decreases.

- By comparing the 3 figures we can see that the least base shear is experienced by the RCC shear walled structure and the highest base shear is experienced by the Steel plate shear walled structure.

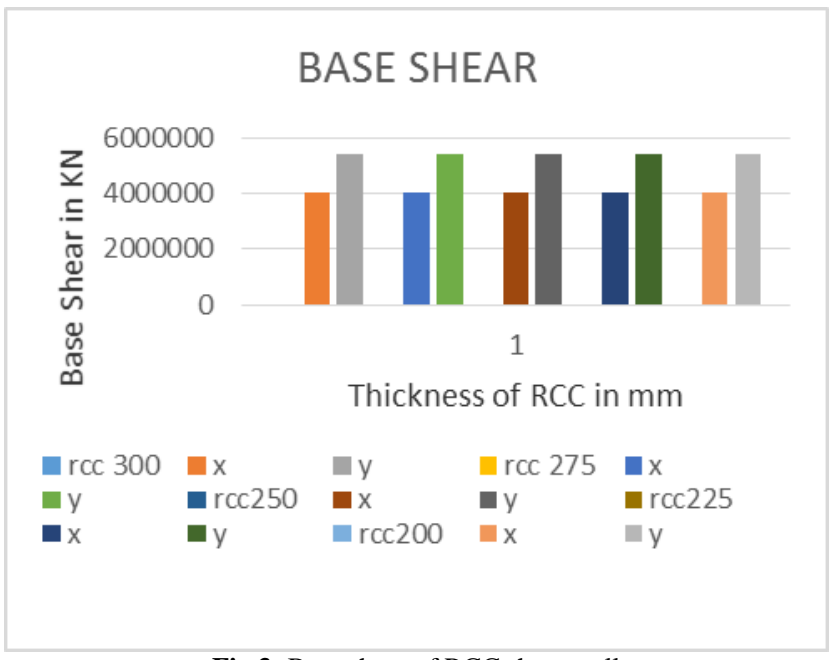

Fig 3: Base shear of RCC shear wall

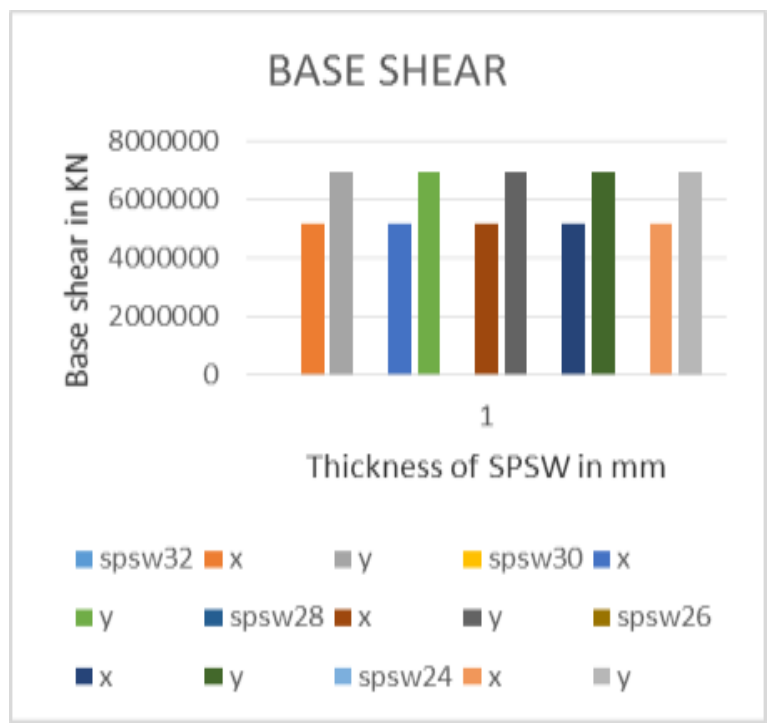

Fig 4: Base shear of Steel plate shear wall

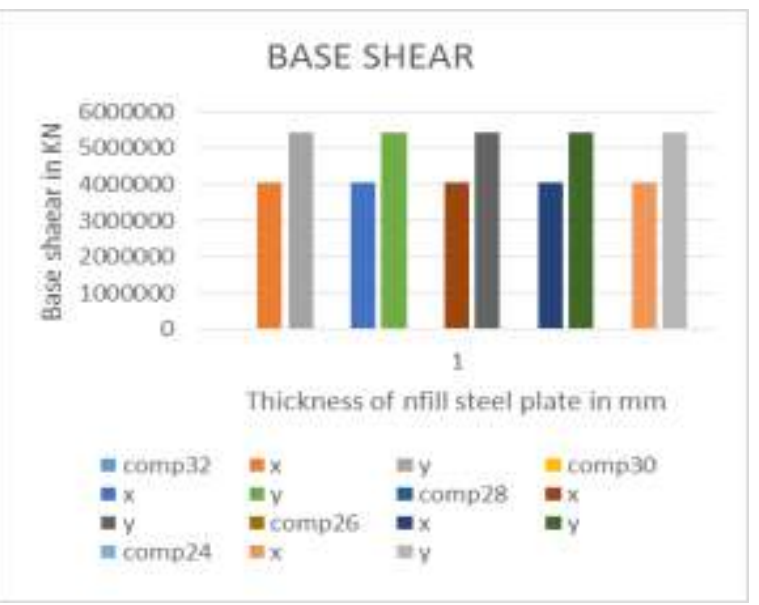

Fig 5: Base shear of Composite shear wall

\section{b. Storey drifts}

- Story drift is defined as the lateral displacement of any one level of the building in relative to the other.

- As per IS $1893-2002$, the storey drift in any storey due to the minimum specified design lateral force, shall not exceed 0.004 times the storey height.

- The story drifts for various thicknesses of RCC shear wall up to $5^{\text {th }}$ storey is depicted by figures $6,7,8,9,10$.

- $\quad$ From the below given data we can see that the thickness of the RCC panel and steel plates are not influencing the storey drift for the basement of the structures.

- The figures $11,12,13,14$ and 15 given below depicts the storey drifts along $\mathrm{x} \& \mathrm{y}$ directions for varying thicknesses of steel plates for the Steel plate shear wall.

- The figures $16,17,18,19$ and 20 given below depicts the storey drifts along $\mathrm{x} \& \mathrm{y}$ directions for varying thicknesses of infill steel plates for the Composite shear wall.

- Only drifts upto $5^{\text {th }}$ floor is taken into consideration for the ease of computation.

- From the below given tables it is evident that the thickness of the RCC panel and the steel infill plate influences the storey drift of the structural system.

- As the thickness of the RCC panel is decreased the storey drift is found to be increasing.

- When thickness of the steel plate is reduced, for the steel plate shear wall and the composite shear wall the storey drift is found to be increasing.

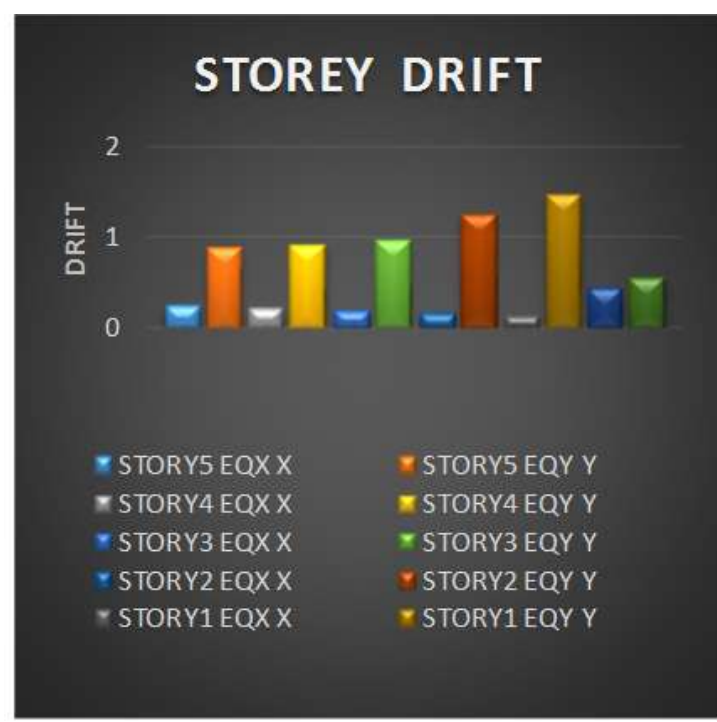

Fig 6:: Storey drift of $200 \mathrm{~mm}$ thick RCC shear wall

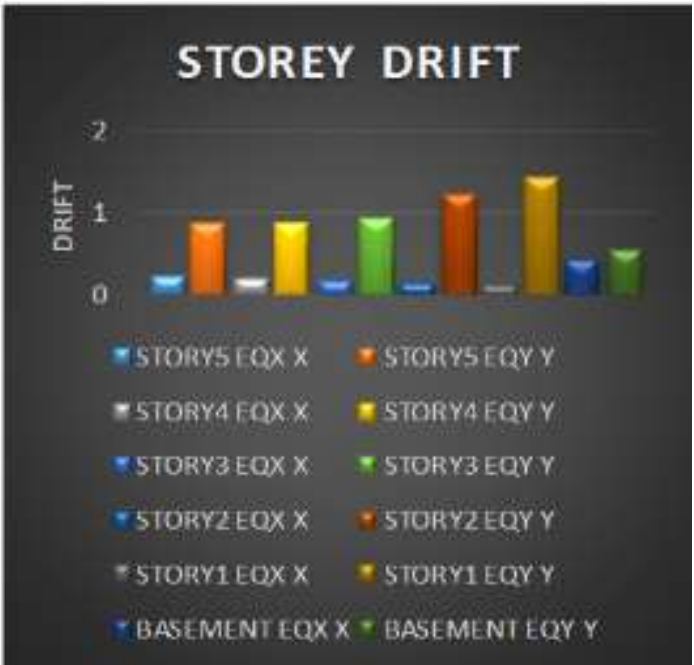

Fig 7: Storey drift of $225 \mathrm{~mm}$ thick RCC shear wall. 


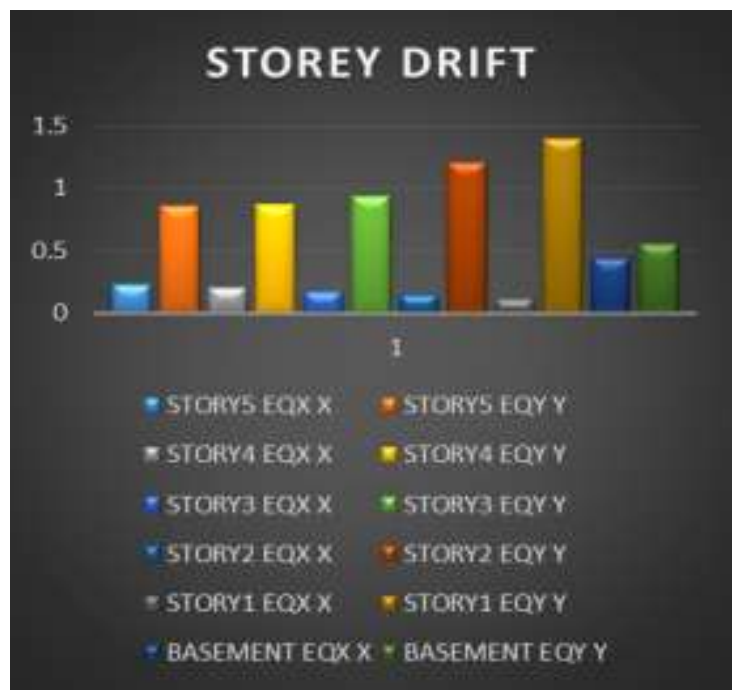

Fig 8: Storey drift of $250 \mathrm{~mm}$ thick RCC shear wall

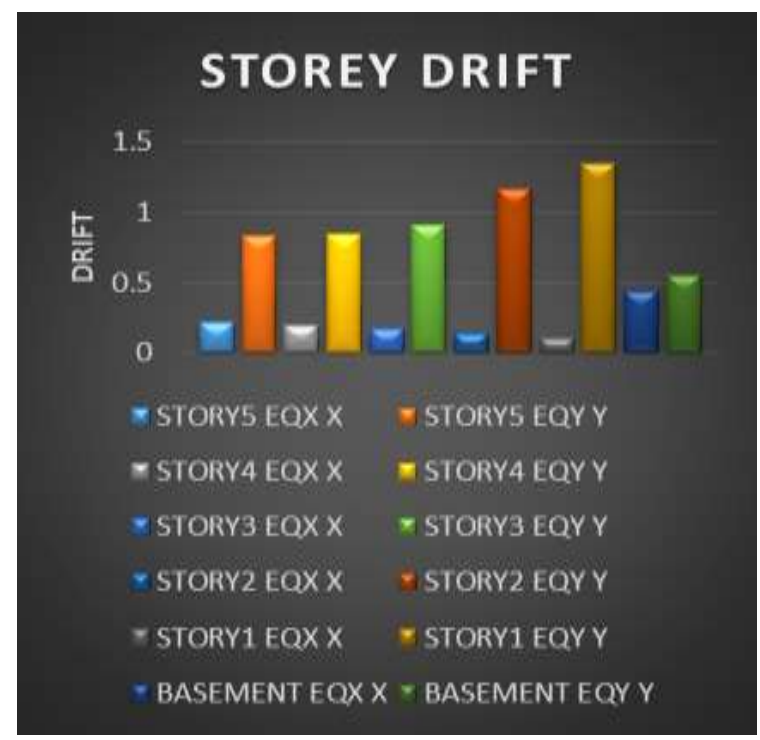

Fig 9: Storey drift of $275 \mathrm{~mm}$ thick RCC shear wall

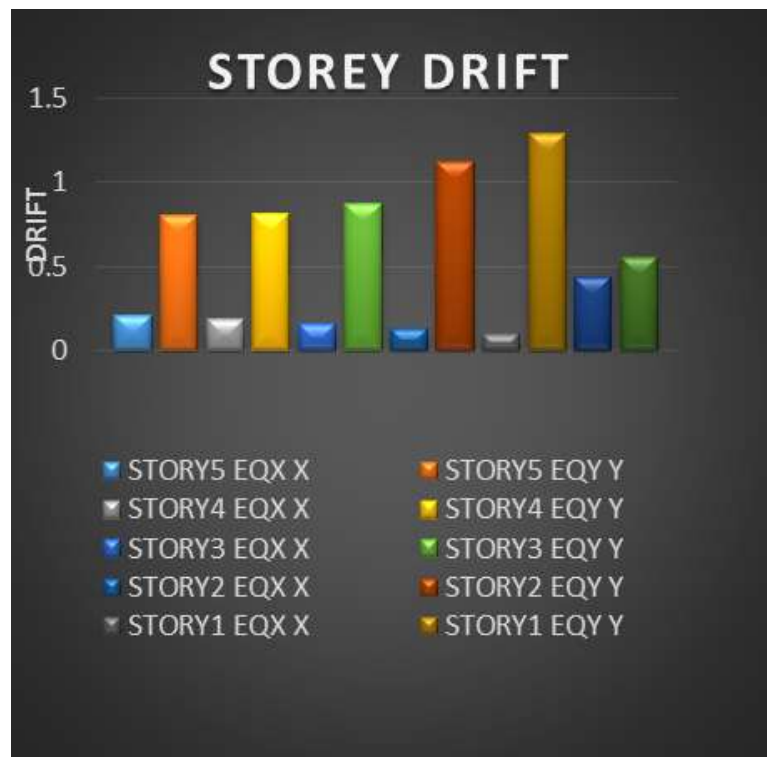

Fig 10: Storey drift of $300 \mathrm{~mm}$ thick RCC shear wall

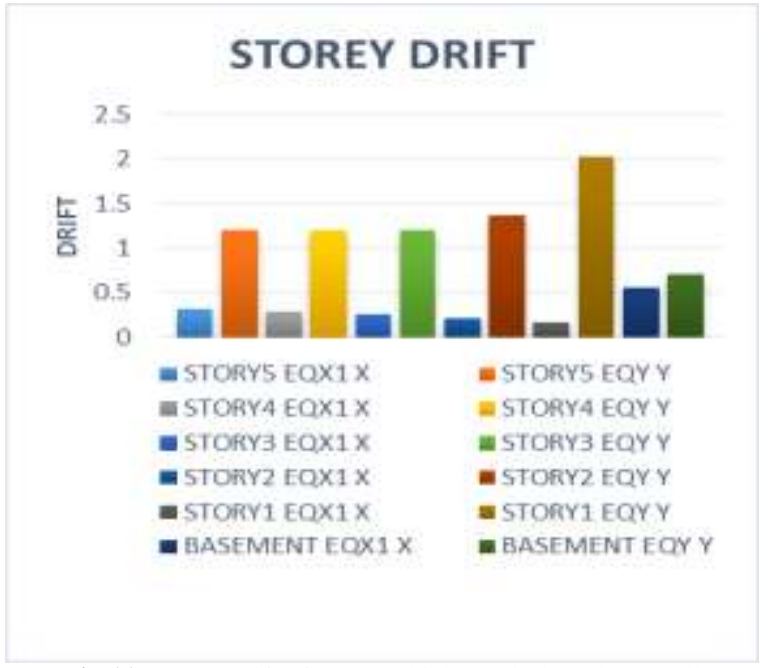

Fig 11: Storey drift of $24 \mathrm{~mm}$ thick Steel Plate shear wall

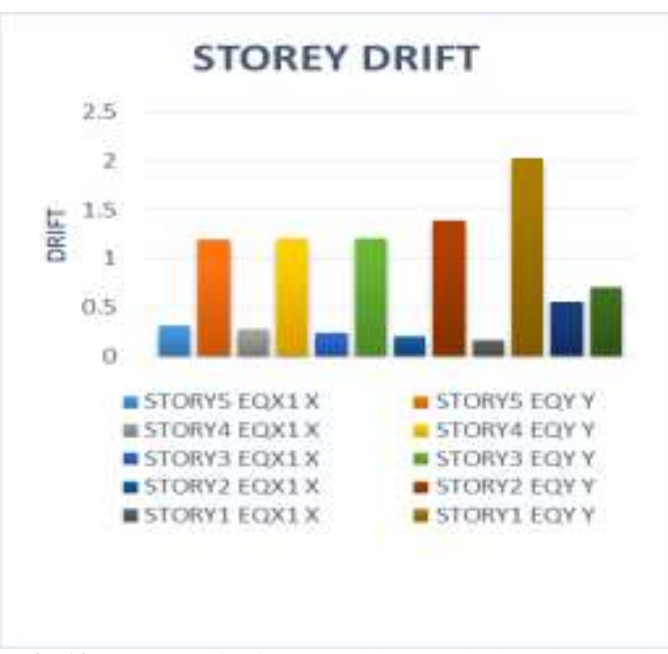

Fig 12: Storey drift of $26 \mathrm{~mm}$ thick Steel Plate shear wall

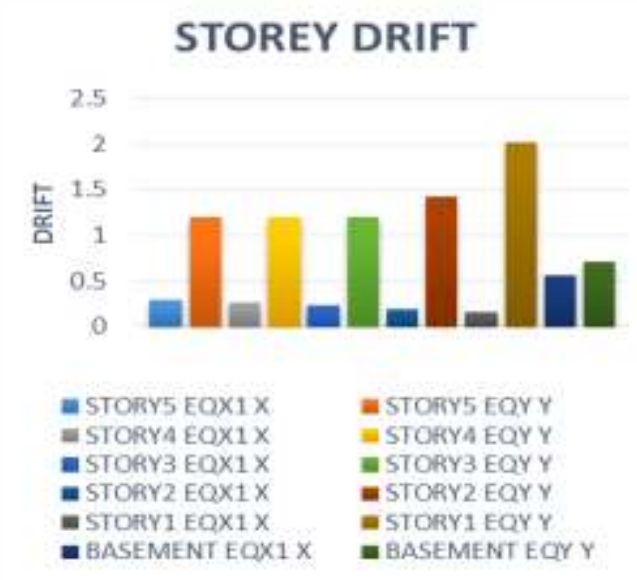

Fig 13: Storey drift of $28 \mathrm{~mm}$ thick Steel Plate shear wall 


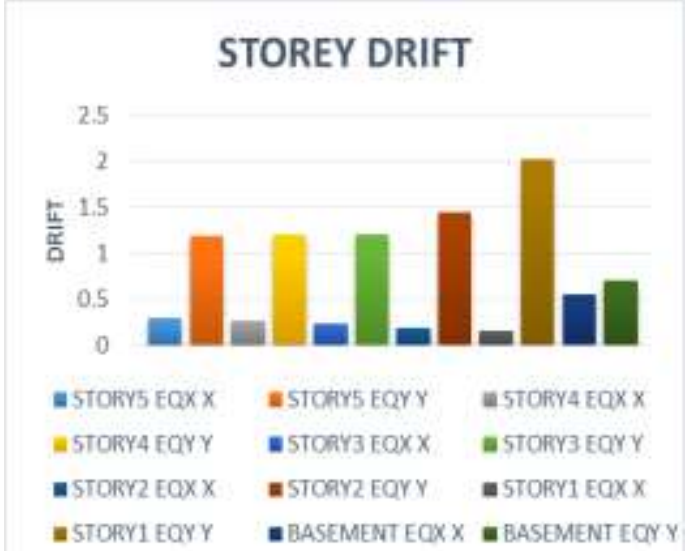

Fig 14: Storey drift of $30 \mathrm{~mm}$ thick Steel Plate shear wall

Fig 15: Storey drift of $32 \mathrm{~mm}$ thick Steel Plate shear wall

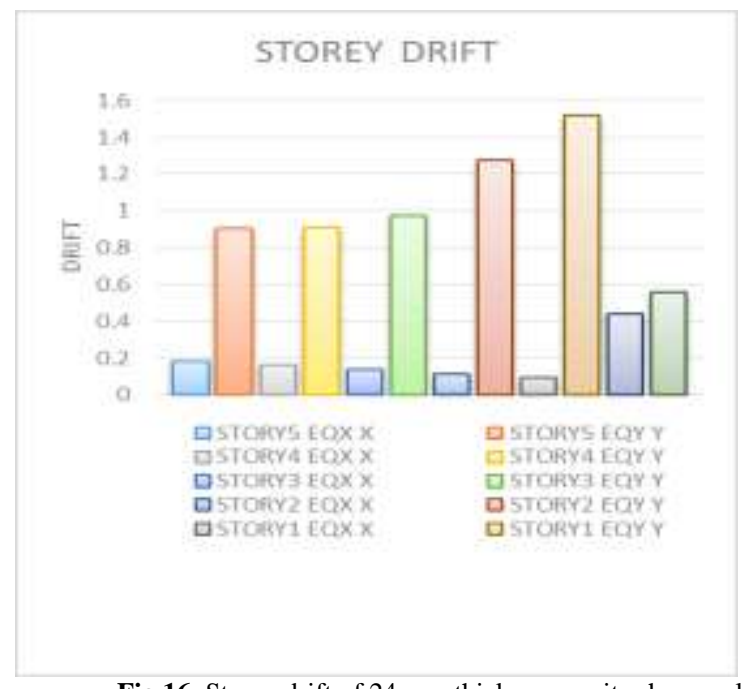

Fig 16: Storey drift of $24 \mathrm{~mm}$ thick composite shear wall

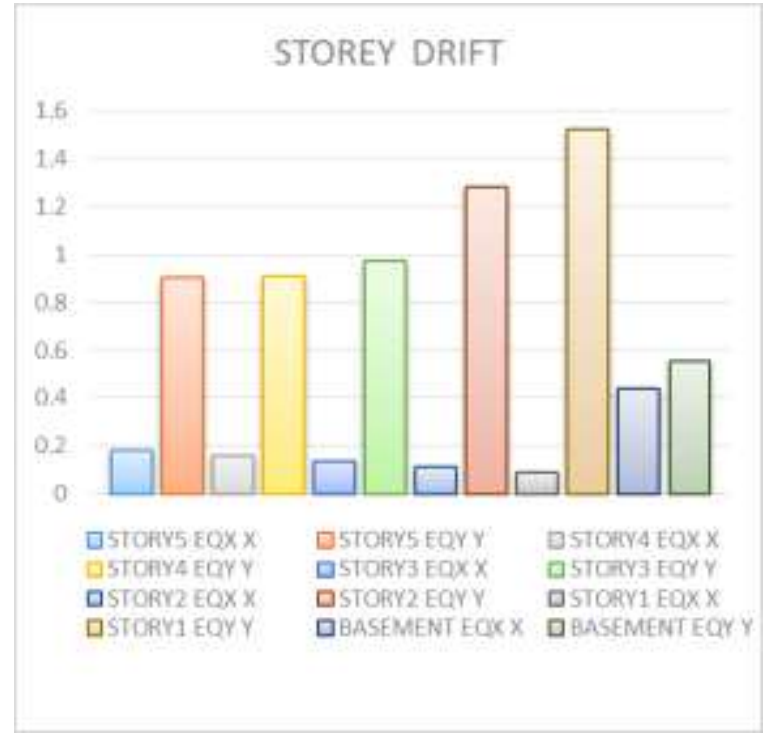

Fig 17: Storey drift of $26 \mathrm{~mm}$ thick composite shear wall

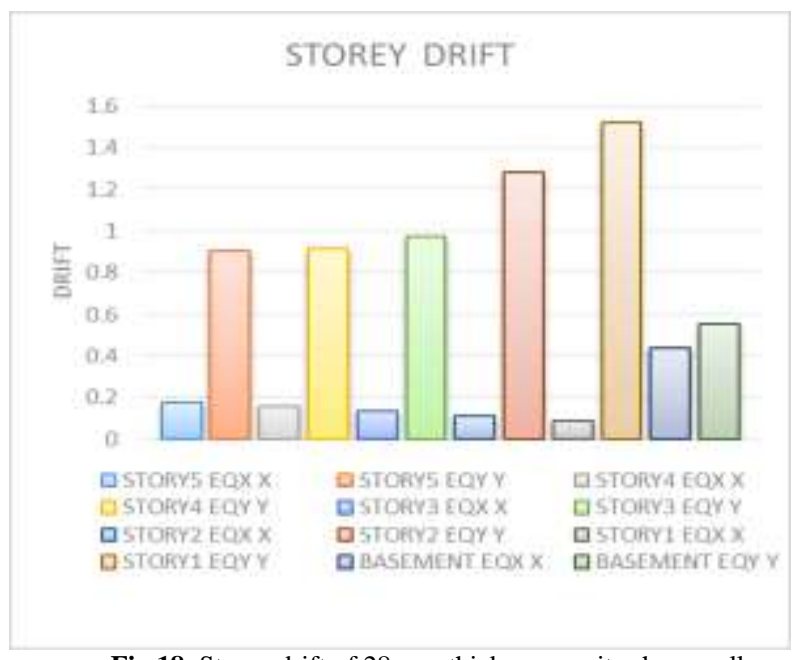

Fig 18: Storey drift of $28 \mathrm{~mm}$ thick composite shear wall

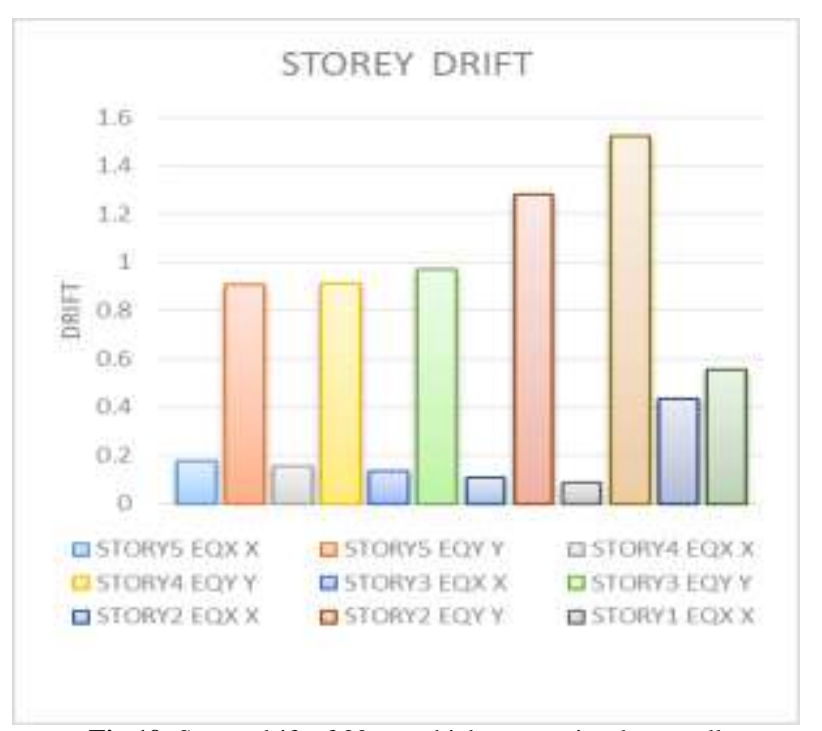

Fig 19: Storey drift of $30 \mathrm{~mm}$ thick composite shear wall 


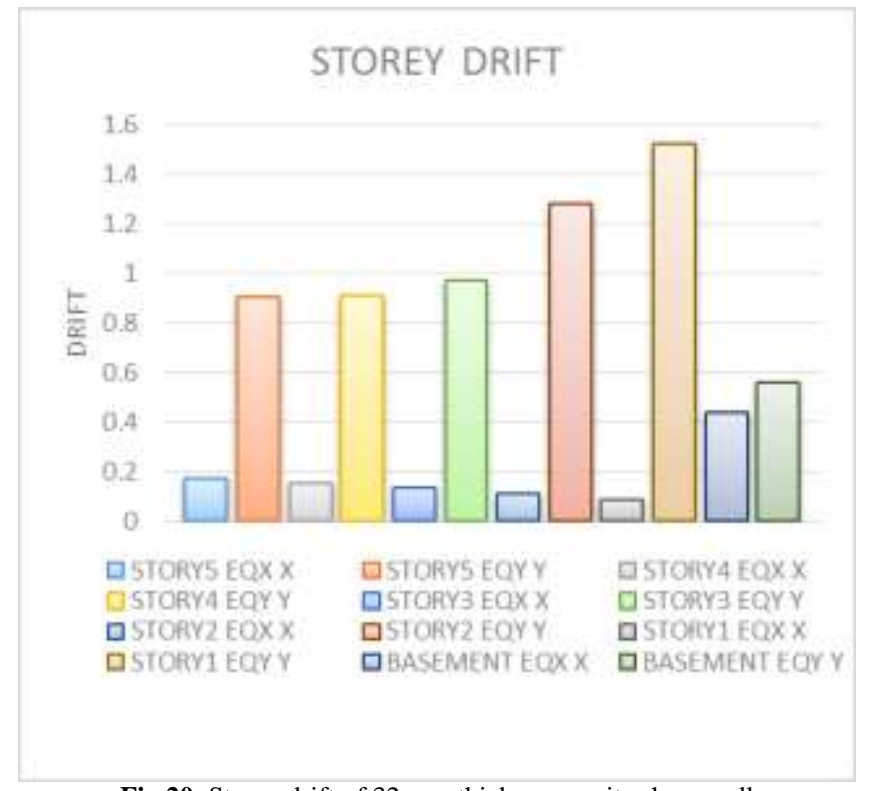

Fig 20: Storey drift of $32 \mathrm{~mm}$ thick composite shear wall

\section{Conclusion}

On the basis of work done so far and analytical investigations conducted in the study, below given general conclusions were raised:

- The base shear slightly reduces when thickness for RCC shear panel and steel plate is decreased.

- The least base shear is experienced by the RCC shear walled structure and the highest base shear is experienced by the Steel plate shear walled structure

- The thickness of the RCC panel and steel plates are not influencing the storey drift for the basement of the structures.

- The thickness of the RCC panel and the steel infill plate influences the storey drift of the structural system.

- As the thickness of the RCC panel is decreased the storey drift is found to be increasing.

- When the thickness of steel plate is decreased,for steel plate shear wall and the composite shear wall the storey drift is found to be increasing.

\section{Acknowledgement}

The author wish to express her gratitude to the structural consultants in Sreegiri consultants for providing support in this study.

\section{References}

[1] Shafaei, S., Farahbod, F. and Ayazi, A., 2017, November. Concrete Stiffened Steel Plate Shear Walls With an Unstiffened Opening. In Structures(Vol. 12, pp. 40-53). Elsevier.

[2] Nassernia, S. and Showkati, H., 2017. Experimental study of opening effects on mid-span steel plate shear walls. Journal of Constructional Steel Research, 137, pp.8-18.

[3] Dan, D., Fabian, A. and Stoian, V., 2011. Theoretical and experimental study on composite steel-concrete shear walls with vertical steel encased profiles. Journal of Constructional Steel Research, 67(5), pp.800-813.

[4] Egorova, N., Eatherton, M.R. and Maurya, A., 2014. Experimental study of ring-shaped steel plate shear walls. Journal of Constructional Steel Research, 103, pp.179-189.

[5] Hosseinzadeh, S.A.A. and Tehranizadeh, M., 2012. Introduction of stiffened large rectangular openings in steel plate shear walls. Journal of Constructional Steel Research, 77, pp.180-192.

[6] Asl, M.H. and Safarkhani, M., 2017. Seismic behavior of steel plate shear wall with reduced boundary beam section. Thin-Walled Structures, 116, pp.169-179.
[7] Nguyen, N.H. and Whittaker, A.S., 2017. Numerical modelling of steel-plate concrete composite shear walls. Engineering Structures, 150, pp.1-11

[8] Dey, S. and Bhowmick, A.K., 2016, May. Seismic performance of composite plate shear walls. In Structures (Vol. 6, pp. 59-72). Elsevier.

[9] Epackachi, S., Whittaker, A.S. and Aref, A., 2017. Seismic analysis and design of steel-plate concrete composite shear wall piers. Engineering Structures, 133, pp.105-123.

[10] Berman, J. and Bruneau, M., 2003. Plastic analysis and design of steel plate shear walls. Journal of Structural Engineering, 129(11), pp.1448-1456.

[11] IS 1893 (Part 1):2002, Indian Standard, "Criteria for Earthquake Resistant Design of Structures", Part 1 General Provisions And Buildings. (Fifth Revision).

[12] IS 800:2007, Code of practice for general construction in steel, Bureau of Indian Standards

[13] IS-875, part 1 (1987), Dead Loads on Buildings and Structures, New Delhi, India.

[14] Limit state design of steel structures (Tata Mc Graw hill education private ltd.) - S K Duggal 